\title{
小型磁気ディスク装置の位置決め機構の耐衝撃特性を向上する設計法*
}

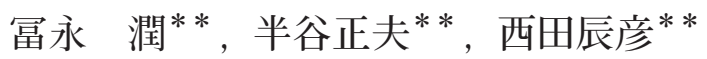

\section{Design Methods to Improve Shock Characteristics for a Swing Arm Actuator of a Hard Disk Drive}

\author{
Jun TOMINAGA, Masao HANYA, Tatsuhiko NISHIDA,
}

\begin{abstract}
In many cases, the compact type hard disk drive (HDD) is employed in mobile devices, and a shockproof design is essential for this kind of application. A swing arm type positioning actuator is vulnerable to the vibration of arm bending modes excited by natural frequency when the shock impulse is imposed.

In this paper, we studied different kind of swing arm type positioning actuators. Their mass and geometry are close each other, however, their vibration characteristics are quite different when the shock impulse is imposed. It turned out that the big difference in vibration response comes from the frequency interval of two arm bending modes in the actuator. The vibration system of three arm actuator consists of the main vibration system with top \& bottom arm and the sub vibration system with the middle arm.

We established the design method to minimize the frequency interval of two arm bending modes in order to improve the shockproof capability by utilizing the dynamic damping effect.
\end{abstract}

Key Words : Hard disk drive (HDD), Swing arm actuator, Mode, Shock characteristics, Vibration

\section{1. 緒 論}

小型磁気ディスク装置 (以下, HDD), 特に2.5inch以下 のディスクを搭載した小型HDDは，モバイル機器で使用さ れることが多く，耐衝撃特性の向上が求められている．最 近のHDDでは記録密度向上のためスライダの低浮上化が進 んでおり, 回転中のディスクに対してスライダをロード/ア ンロードさせるランプロード方式が採用されている。この 方式は非動作時の耐衝撃特性の向上にも効果があることか ら，小型HDDに展開が進んでいる11.

一方, 動作時の耐衝撃特性の向上に対する問題はスライ ダの跳躍である。これは，スライダ質量やサスペンション 形状によって決まる等価質量とサスペンション荷重が大き く影響しているが, 特にサスペンションの軽量化が有効で ある。しかし，サスペンションが対応できるサーボ带域を 広くするためには, 高剛性化の必要がある。一般的に高剛 性化を実現するには質量を増加させる必要があるため, 軽 量化と高剛性化は相反する特性となる。したがって, サス ペンションはこれらの特性を高いレベルで両立することが
要求される。伊藤らはパーシャルエッチング加工を導入し て, 同一部材で形成されたロードビームと荷重曲げ部の厚 みを独立に設計することを可能とした。これにより，ねじ れ共振モードの周波数を向上させるとともに外部から衝撃 が加わった際にスライダが跳躍して着地時にデイスクにダ メージを与える問題についても大幅に改善した22.

しかしサスペンションだけではなく, 基台 (ベース) 剛 性やサスペンションを支持する摇動型位置決め機構（以下， キャリッジ）も動作時の耐衝撃特性に大きな影響を与える. 伊藤らは，基台に扔いて衝撃が加わった際に励振されやす いのは底板が太鼓状に変形する最低次の固有振動モードで あり，この固有振動数をなるべく高く設計することが重要 であると報告している。一方，キャリッジにおいては摇動 軸ピボット部の弾性変位に起因する固有振動モードとアー ム部の曲げに起因する固有振動モードがあり，前者の方が 低次となる。この低次側となる摇動軸ピボット部の弾性変 位に起因する固有振動モードは, 制御帯域を制限するため, 小野らがさまざまな提案をしているが，ピボット軸受部の 
剛性を大きくすることによりこの固有振動数を高くするか, 軸受部の減衰を大きくして安定化を図るといった設計がお もに行われており，これは耐衝撃特性の向上にも効果があ ると考えられる3 . しかし衝撃が加わったときは，この固有 振動モードだけでなくアーム部の曲げに起因する固有振動 モードも励振される。このため, アーム部の軽量化が望ま れる. しかし，キャリッジもサスペンションと同様にサー ボ帯域を広くするために高剛性化の必要があるため, 軽量 化と高剛性化を両立することが要求される.

そこで本論文では，キャリッジのアーム形状や重量がほ とんど同一であるが，衝撃が加わったときの応答特性が異 なる二つのサンプルを対象に，数值計算を用いてこの特性 の差異が生じた要因を明らかにする研究を行った。この結 果, キャリッジの剛性を向上するのではなく, その固有振 動数を調整することで, アーム部の曲げに起因する固有振 動モードの振幅を抑制し，動作時の耐衝撃特性を向上する 設計法を確立した。

\section{2. 比較するニつのキャリッジサンプル}

Fig. 1に二枚のディスクに対応するキャリッジを示す. キャ リッジはスライダをディスク上で摇動方向に移動させるた めの軸受が中心に設置されている. そこから, 形状の等し いアルミニウム製の三本のアームが突出する形状となって いる。このアームを上方からトップアーム, ミドルアーム, ボトムアームと呼ぶこととする。トップアームとボトムア 一ムの先端には, サスペンションとスライダが一個装着さ れ，ミドルアームの先端には二個装着される。ミドルアー ムの厚さは，二つのサスペンションとスライダの支持に必 要な剛性を確保するため, トップアームとボトムアームよ りも厚くなっている。また，三本のアームの反対側には樹 脂で部分的に覆われたコイルが装着されている。このキャ リッジは軸受の上下面の二箇所で基台にねじ締結される.

Table 1に二つの耐衝撃特性が異なるキャリッジのサンプ ルの形状を示す。これらをサンプルAとサンプルBとする. 各 アームの厚さと穴形状に微小な差異があるが，重量や剛性 に大きな差異はない.これらのサンプルに搭載されるサス ペンションとスライダ，および軸受やコイルは同一である. したがって，これらのサンプルの耐衝撃特性の差異は，ア

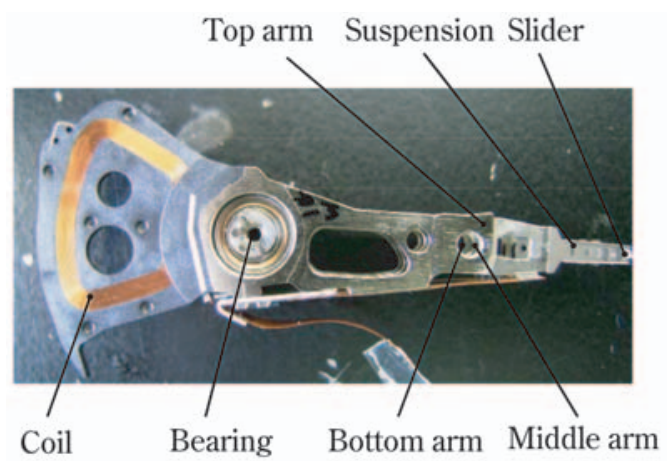

Fig. 1 Swing arm actuator (Carriage)
一ムの厚さや形状の微小な差異が要因であると考えられる.

これらのサンプルの耐衝撃特性は，スイングアーム式の 衝撃試験機を使用して実験的に取得した。サンプルの各ア ームにはサスペンションとスライダを搭載し, 軸受の上下 面の二箇所を剛性の高い治具にねじ締結した。そして加速 度が $8330 \mathrm{~m} / \mathrm{s}^{2}(850 \mathrm{G})$ ，作用時間が $0.4 \mathrm{~ms}$ の正弦半波となる 衝撃加速度を入力した．Fig. 2にそれぞれのサンプルに衝撃 加速度を入力したときの各アームの加速度振幅の応答特性 の実験結果を示す。サンプルAではトップアームとボトム

Table 1 Carriage sample.

\begin{tabular}{|l||l|l|}
\hline & Sample A & Sample B \\
\hline Geometricdifferencei & & \\
\hline $\begin{array}{l}\text { Thickness } \\
\text { (Top \& Bottom arm) }\end{array}$ & $0.90 \mathrm{~mm}$ & \\
\hline $\begin{array}{l}\text { Thickness } \\
\text { (Middle arm) }\end{array}$ & $1.10 \mathrm{~mm}$ & $1.11 \mathrm{~mm}$ \\
\hline
\end{tabular}

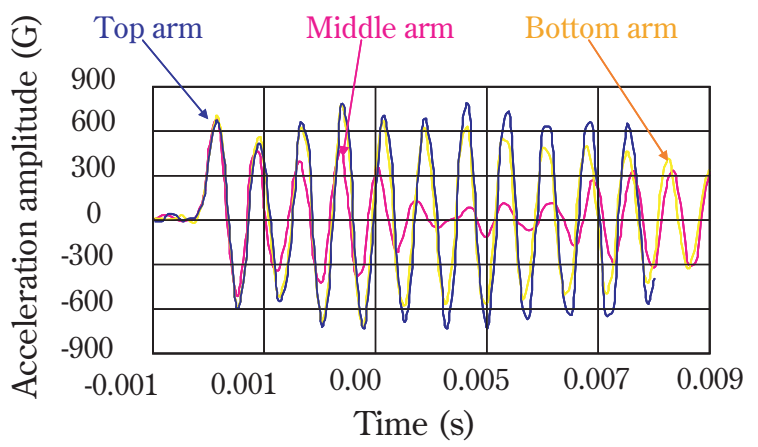

Sample A

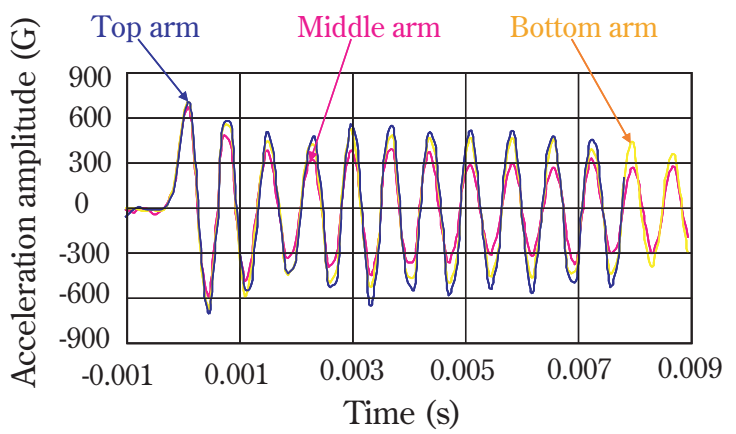

Sample B

Fig. 2 Transient response (Experimental result) 
アームの振幅が大きく, ミドルアームの振幅が小さくなっ た。そして，トップアームとボトムアームの第四波と第七 波の振幅が大きくなった。この二つの波の間隔は約 $0.00225 \mathrm{~s}$ で，周波数では $444 \mathrm{~Hz}$ となる。この現象は，サンプルBにお いても第二波と第五波で見られる。この二つの波の間隔は 約 $0.00242 \mathrm{~s}$ で, 周波数では $419 \mathrm{~Hz}$ となる。これは, 後述する サンプルの固有振動モードにおいて，モード1とモード4の 結合による「うなり」であると考えられる.

ここで，それぞれのサンプルの三本のアームの振幅の絶 対值に着目すると, サンプルAのトップアームの振幅が最 も大きい.これは, サンプルAのトップアームが最もディ スクに接触しやすく, 耐衝撃特性が良くないことを意味す る。言い換えれば, サンプルBは各アームの振幅の最大值 が小さいため, ディスクに衝突しにくく，耐衝撃特性が良 好であると言える。

\section{3. 数値計算方法}

キャリッジの運動は, 衝突や摩擦といった非線形特性を 示す現象が作用しないため, 本論文では線形特性を示す系 の運動と仮定する。こうした系に任意の周波数成分を持つ 正弦波の運動を加えると, その応答も同じ周波数の正弦波 の運動となる.

ここで，キャリッジに衝撃加速度を印加したときの応答 特性を考える. 印加した衝撃加速度は，0.8msの周期の正弦 波の半周期に近い波形となることから， $1250 \mathrm{~Hz}$ の振動数と 考えることができる。この衝撃加速度が加わったとき，キ ヤリッジの応答特性は, 第一波がこの振動数となり, その 後は自由振動（系の固有振動）となる。したがって，キャ
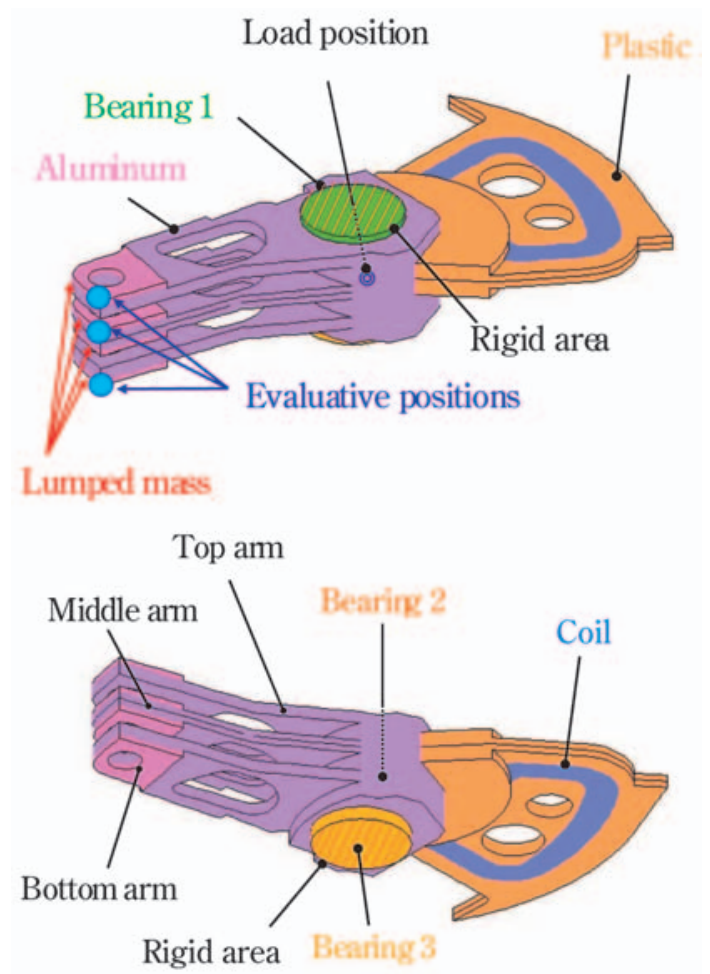

Fig. 3 Calculation model (Calculation result)
リッジの応答特性は系の固有振動モードの線形和だけで表 現することができる4).

これより，二つのサンプルの応答特性の差異は，各アー ムの固有振動モードの差異であると考えられる。しかし， $1000 \mathrm{~Hz}$ 以上の固有振動数を持つ三本のアームの挙動を実験 で把握することは困難であることから，数值計算を使用し てアームの固有振動モードと固有振動数を算出し, これら の差異を明らかにすることとした。

数值計算は，汎用FEMソフトであるABAQUS Standard Ver.6.54を使用した。そして線形摂動法により，固有振動 モードと固有振動数を算出した。また，これらの固有振動 モードを利用するモーダル法を用いて周波数応答特性を算 出した. Fig. 3に数值計算モデルを示す. 使用した要素は六 面体一次低減積分要素で，要素数は約17200である。なお， スライダとサスペンション，コイル，軸受については，以 下のようにモデル化した。

・スライダとサスペンション

形状を簡略化し，それらに相当する集中質量 $(0.69 \mathrm{~N})$ をトップアームとボトムアームの先端には一つ, ミ ドルアームの先端には二つ搭載した。

・コイル

体積と重量が実験に使用したサンプルと等しくなる ように密度を調整した。

・軸受

上層部，中層部，下層部の三層構造とし，固定箇所 となる上層部と下層部のヤング率を小さくし，ポア ソン比を大きくした.

境界条件は，軸受の上層部と下層部を完全固定し，軸受 部中心部の一節点に上下方向に $10 \mathrm{~N}$ の力加振を加えた.

減衰については，モデル内の材料ごとの減衰係数を臨界 減衰比として定義した複合モーダル減衰を使用した。 Table 2に各物性值を示す。

Table 2 Material property.

\begin{tabular}{|c||c|c|c|}
\hline & Aluminum & Plastic & Coil \\
\hline \hline Young modulus (MPa) & 67.6 & 19.6 & 0.294 \\
\hline Specific gravity & 2.73 & 1.53 & 7.1 \\
\hline Poisson ratio & 0.3 & 0.3 & 0.3 \\
\hline Damping coefficient & 0.001 & 0.01 & 0.01 \\
\hline
\end{tabular}

\begin{tabular}{|c||c|c|c|}
\hline & Bearing 1 & Bearing 2 & Bearing 3 \\
\hline \hline Young modulus (MPa) & 0.0294 & 205.8 & 0.0294 \\
\hline Specific gravity & 7.8 & 7.8 & 7.8 \\
\hline Poisson ratio & 0.49 & 0.3 & 0.49 \\
\hline Damping coefficient & 0.01 & 0.001 & 0.01 \\
\hline
\end{tabular}

Table 3 Mode shape (Calculation result)

\begin{tabular}{|l||c|c|c|c|}
\hline \multirow{2}{*}{$\begin{array}{l}\text { Displacement. } \\
\text { I. }\end{array}$} & Mode.1 & Mode.2 & Mode.3 & Mode.4 \\
\cline { 2 - 5 } & & & & \\
\hline Sample A & $1281 \mathrm{~Hz}$ & $1405 \mathrm{~Hz}$ & $1464 \mathrm{~Hz}$ & $1723 \mathrm{~Hz}$ \\
\hline Sample B & $1319 \mathrm{~Hz}$ & $1483 \mathrm{~Hz}$ & $1496 \mathrm{~Hz}$ & $1724 \mathrm{~Hz}$ \\
\hline
\end{tabular}




\section{4. 数値計算による固有振動モードの差異}

Table 3に, サンプルAとサンプルBの固有振動モードと固 有振動数を示す。なお本論文では, 固有振動モードを振動 数が低い方からモード 1 , モード $2 \cdots$ と呼ぶこととする. 固 有振動モードは, サンプルAとサンプルBで同一である。モ ード1はキャリッジ全体が摇動振動するモード，モード 2 は トップアームとボトムアームが逆位相で振動するモード, モード3はミドルアームが振動するモード, モード4はコイ ルが振動するモードである。ここで，モード1は摇動軸ピボ ット部の弾性変位に起因する固有振動モードであり, モー ド2とモード3がアーム部の曲げに起因する固有振動モード である。そこで，本論文ではアームの基本モードであるモ ード2とモード3に着目する。サンプルAではモード2とモー ド3の固有振動数の間隔が約 $50 \mathrm{~Hz}$ であるのに対し, サンプ ルBではモード 2 とード 3 の固有振動数の間隔が約 $10 \mathrm{~Hz}$ と 狭い。これより, サンプルAとサンプルBの固有振動モード の大きな違いは，モード2とモード3の固有振動数の間隔の 違いであることがわかる。

Fig. 4にサンプルAとサンプルBの周波数応答特性を示す. サンプルBはサンプルAと比較して, モード2とモード3のト ップアームとボトムアームの振幅が小さい. 一方, ミドル アームの振幅はモード2において大きい. 参考ではあるが, モード1とモード4においては，サンプルAとサンプルBの各 アームの振幅に大きな差異はない。これより，サンプルB はサンプルAと比較して，モード2とモード3におけるトップ アームとボトムアームの振幅が小さいため, 衝撃が加わっ たときの応答特性において, トップアームとボトムアーム の振幅が小さくなると考えられる.

\section{5. 差異が生じる要因とそれを利用した設計法}

ここでは，「トップアームとボトムアームが振動するモー ド2の固有振動数とミドルアームが振動するモード3の固有振 動数の間隔が小さい」ことと,「モード2とモード3において
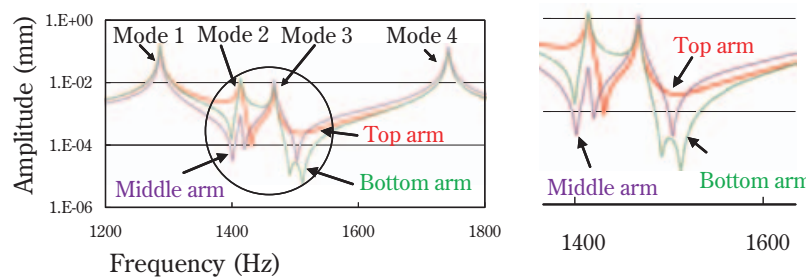

Sample A
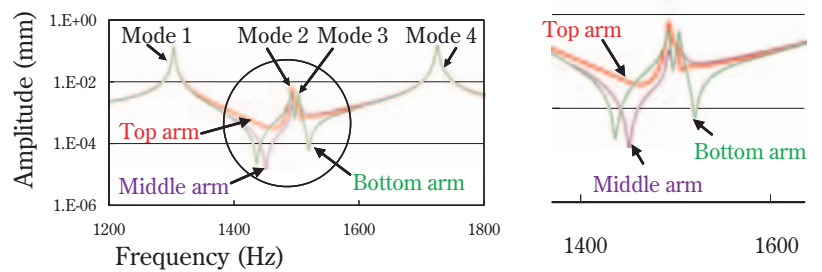

Sample B

Fig. 4 Frequency response (Calculation result)
トップアームとボトムアームの振幅が小さい（ミドルアー ムの振幅が大きい)」ことの因果関係を明らかにし，それを 利用したキャリッジの耐衝撃特性を向上する設計法を示す.

そこで，各アームの固有振動モードと固有振動数の関係 を調べるために，トップアーム，ミドルアーム，ボトムア ームの三本のアームのみからなる構造体のモデル（以下， モデル3）と，ミドルアームからなる構造体のモデル（以下， モデル1）とトップアームとボトムアームからなる構造体の モデル（以下，モデル2）の固有振動モードを考える. Fig. 5にこれらの構造体の数值計算モデルと境界条件を示す。こ れらのモデルは上下方向を加振方向とし，その方向の自由 度があるように弾性支持する。物性值はTable 2で示したア ルミニウムとし, 衝撃加速度は10Nの力加振とする. Fig. 6 に数值計算によって算出した固有振動数と固有振動モード を示す。ただし，ここでは構造体と弾性支持の系による固 有振動モード（アーム以外の固有振動モード）は示してい ない。これより，モデル3の固有振動モードはトップアーム とボトムアームが振動するモード（以下，モード1）とミド ルアームが振動するモード（以下，モード2）となる。すな わち，モード1がモデル 2 ，モード 2 がモデル 1 の固有振動モー ドと同一となる。したがって，モデル3はモデル 1 の振動系 とモデル2の振動系を合わせた振動系であると考えられる。

次に，モデル3の固有振動数と各アームの振幅の関係を考

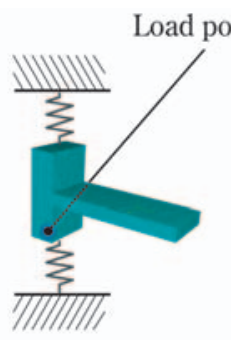

Model 1

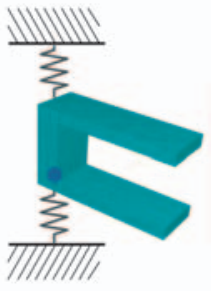

Model 2

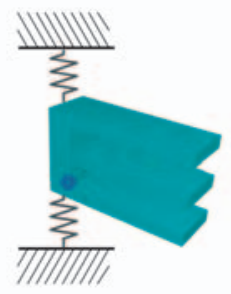

Model3
Fig. 5 Concept model (Calculation model)

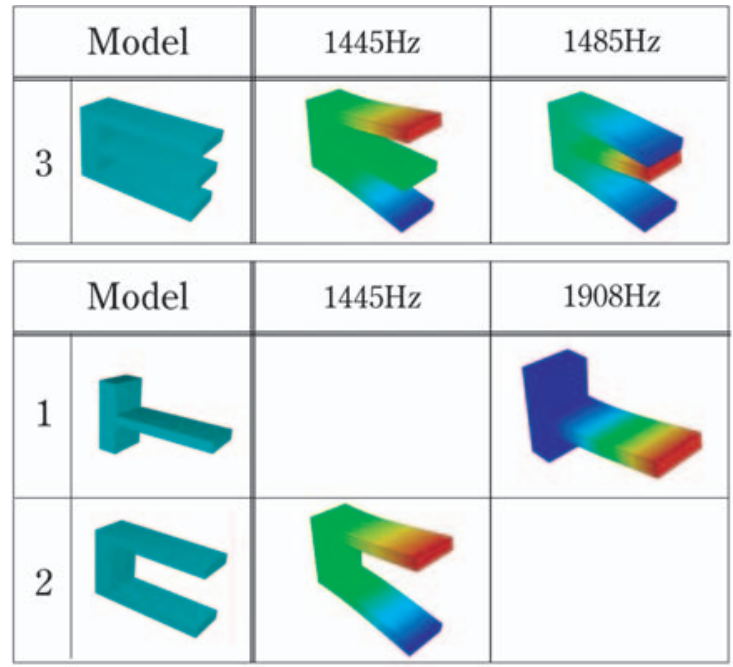

Fig. 6 Modal shape (Concept model) 


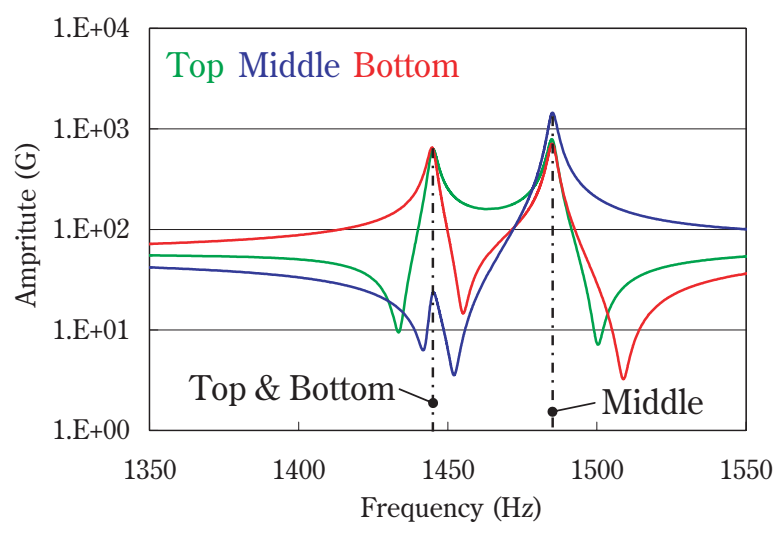

Model 3A

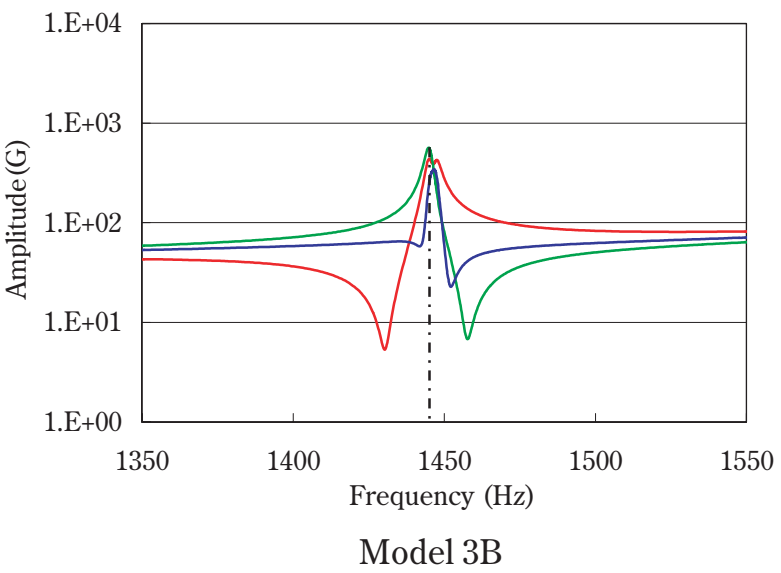

Fig. 7 Frequency response (Concept model)

える、そこで，モデル3においてモード1の振動数とモード2 の振動数の間隔が大きい場合をモデル $3 \mathrm{~A}$ ，小さい場合をモ デル3Bとする，モデル3Bでは，ミドルアームの厚さを小さ くしてモード2の振動数を小さくすることで, 二つの固有振 動数を近づけた. Fig. 7に数值計算によって算出した周波数 応答特性を示す，モデル3Bはモデル3Aと比較して，二つの 固有振動モードに扔ける各アームの振幅が重なり, トップ アームとボトムアームの振幅が小さく，ミドルアームの振 幅が大きい。これより，モデル3Aとモデル3Bは，それぞれ キャリッジのサンプルAとサンプルBと同様の現象となって いる。 そして，二つの振動系の固有振動数の間隔の違いに よって，モード2とモード3に扔ける各アームの振幅が変化 している。 これより，三本のアームから構成されるモデル3 は，トップアームとボトムアームから構成される系を主系 とし，ミドルアームから構成される系を付加系とした振動 系となり，モデル3Bのように主系と付加系の固有振動数の 間隔が小さいときは，付加系がダイナミックダンパの作用 をする（主系の振幅が小さくなり，付加系の振幅が大きく なる）と考えられる5 .

以上のことから，三本のアームからなるキャリッジの耐
衝撃特性を向上するためには，トップアームとボトムアー ムが振動するモードの固有振動数とミドルアームが振動す るモードの固有振動数の間隔を小さくして，ミドルアーム にダイナミックダンパの作用をさせる方法が有効である. これにより, 衝撃が加わった後の三本のアームの応答振幅 の最大值を小さくすることができる.

\section{6. 結 論}

本論文では，キャリッジのアーム部の形状や重量がほと んど同一であるが，衝撃が加わったときの耐衝撃特性が大 きく異なる二つのキャリッジサンプルについて，数值計算 を用いてこの特性の差異が生じた要因を明らかにする研究 を行い，耐衝撃特性を向上する設計方法を示した，以下に 結論を示す。

1）キャリッジのアームの基本モードはモード2とモー ド3である。

2）耐衝撃特性の異なるキャリッジのサンプルの差異は, モード2とモード3の固有振動数の間隔の違いである. この間隔が小さいと，周波数応答特性においてトッ プアームとボトムアームの振幅が小さくなるため, 衝撃が加わったときの応答特性に抢ける三本のアー ムの振幅の最大值が小さくなる。すなわち，耐衝撃 特性が良好となる。

3）三本のアームから構成される構造体は，トップアー ムとボトムアームを主系とし，ミドルアームを付加 系とする振動系となる。

4）トップアームとボトムアームが振動する固有振動数 とミドルアームが振動する固有振動数の間隔を小さ くすることにより，ミドルアームがダイナミックダ ンパの作用をさせることができる。これにより，衝 撃が加わったあとの応答特性に扔けるトップアーム とボトムアームの振幅を小さくし，三本のアームの 振幅の最大值を小さくすることができる.

最後に本研究を進めるにあたり，サンプルの提供をして 頂いた富士通株式会社の林丈雄氏に謝意を表する。

\section{参考文献}

1）伊藤淳，柳原茂樹，東芝レビュー，57-7（2002），14.

2）山本耕太郎，大坪康郎，東芝レビュー，57-7 (2002), 8.

3）例えば，寺本律，小野京右，日本機械学会論文集（C 編), 55-520(1989), 2919.

4）長松昭男，“モード解析入門”，(1993)，P88，コロ ナ社.

5）原文雄, “機械力学”, (1988), P.193, 裳華房. 